\title{
The Linkage Between Turkish Managers' Leadership Orientations and Their Innovativeness Feature: An Empirical Study
}

\author{
Evren Ayranc1 ${ }^{1} \&$ Nurdan Çolakoğlu ${ }^{1}$ \\ ${ }^{1}$ Faculty of Economics and Administrative Sciences, Istanbul AREL University, Istanbul, Turkey \\ Correspondence: Evren Ayranc1, Cihangir Mah. Mesrutiyet Cad. Sila Sok. No: 9/1 D.13 34310 Avcilar, Istanbul, \\ Turkey. Tel: 90-532-405-4094. E-mail: xonox@mynet.com
}

Received: June 14, 2013

Accepted: July 3, 2013

Online Published: July 25, 2013

doi:10.5539/ibr.v6n8p26

URL: http://dx.doi.org/10.5539/ibr.v6n8p26

\begin{abstract}
The dual issues of leadership features and innovativeness constitute an important component of the related literature along with the studies focusing on the connections between these two. The current study considers this connection with the notion that innovativeness should be included as a feature of a leader, but it also moves further by trying to understand how leadership orientations and innovativeness are patterned together within the leadership concept. To this end, the authors of the current study collect data from the top managers of businesses in the Istanbul Leather Organized Industrial Zone and perform inferential analyses. It is discovered that leadership orientations have three and that innovativeness has five distinct factors. A structural equation model that includes all of these factors together under the concept of leadership is proposed. Although all of the innovativeness factors are found to be integrated within this model, only one factor for leadership orientations people orientation - can be integrated within the model. In other words, innovativeness can entirely be included within the proposed model of leadership, but leadership orientations can only partially be included. Most of the innovativeness factors are positively and moderately related to leadership, albeit assertiveness is not considerably favored. Overall, the emphasis appears to be on people oriented and innovative leadership.
\end{abstract}

Keywords: leadership, innovativeness, managers, Turkey

\section{Introduction}

Leadership has been an important issue since the ancient times (Davis \& Luthans, 1979) and has also been a prominent subject of scientific exploration by countless scholars for approximately the last 150 years (e.g., Galton, 1869; Terman, 1904; Stogdill, 1948; Kark \& Van Dijk, 2007). Innovativeness, albeit a newer concept than leadership, has been attracting scientific interest since the 1950s (Guilford, 1967), and it appears that this interest has grown, particularly over the last few years (Chesbrough, 2004; Herzog, 2008; Chiaroni et al., 2011). All of these facts inevitably lead to an investigation of the possible relationships between these two concepts, and some studies (e.g., Jaskyte, 2004) claim evidence for these relationships.

Despite this evidence, there are some shortcomings found by the authors of this current study. It is, primarily, notable that there are hardly related studies, and so, there is a weakness of in-depth and continuous analysis of this relationship. A more noteworthy point is that there are even fewer studies (e.g., Gumusluoglu \& Ilsev, 2009; Mogulkoc, 2009; Ayranci, 2011) that focus on this relationship within the Turkish business context. There is also a lack of leadership decomposition that can identify which aspects of leadership orientation can be considered along with the leaders' innovativeness features, if the leadership role does include innovativeness. According to the authors, many of the studies (e.g., Deschamps, 2003) claim that innovativeness should be integrated within a general model of leadership but do not prove their claims empirically.

With all of these concerns in mind, this current study is believed to be a noteworthy addition to the relevant literature. The authors abide by the general belief that innovativeness should be a feature of leadership and that some leadership orientations should be linked with the leader's innovativeness within an integrative model. To arrive at this integrative model, the authors collect data from Turkish top managers and discover the statistical structure of leadership orientations and innovativeness. The discovered structures are aggregately merged in the authors' proposed integrative model. One clear result is that leadership includes all of the factors of innovativeness and only one orientation factor - people orientation. The results indicate that innovativeness is moderately and, overall, positively related to leadership, with the exception that being assertive as a part of 
innovativeness is not much preferred when leadership is in question.

\section{The Nexus between Innovativeness and Leadership}

Despite many different and challenging definitions of innovativeness, a common point appears to be the emphasis on newness, in other words, unconventionality. Innovativeness is generally perceived to be the capacity or capability that enables a new or unconventional way of thinking or behaving (Guilford, 1967; Gopalakrishnan \& Damanpour, 1994; Ahmed, 1998) that may be used to solve problems (Wakefield, 1992), make distinctions among people (Riza, 2000), or sense what is wrong to develop original solutions (Torrance \& Wu, 1981). This capacity or capability is generally represented using two viewpoints. The first viewpoint claims that uncovering innovativeness depends on an investigation into the results of the innovative actions (Damanpour, 1992; Wolfe, 1994). The second viewpoint accepts that innovativeness is not intended to emerge instantly; it is rather facilitated via a process. While some scholars (e.g., Rogers, 1983; Vecchio, 1988) provide a general consideration of the innovation process, others (Ahmed, 1998; Chesbrough, 2004) try to customize these steps according to the business context. The use of special applications including synectics (Nolan, 2003), meditation (Neale, 2006), and cognitive mapping (Swan \& Newell, 1994) may also be considered for this process.

Because leadership is basically about choosing (Collins, 2001), calling (Chamberlain, 2004), equipping (Eden, 2001) and influencing (DuBrin, 1997) people to carry out the required duties to reach the desired goals (Staub, 1996; Ulrich et al., 1999), a leader is expected to benefit from innovativeness that is aimed towards people, duties, or potentially both (Bennis, 1997). Innovativeness may be used by the leader to gather people around the obvious or implied organizational purposes (Eyal \& Kark, 2004) or it may be used in the leader's decision regarding what to do (Eigen \& Siegel, 1989). Some scholars (e.g., Bennis, 1989; Howell \& Higgins, 1990) move one step ahead and contend that leadership is actually about delivering newness and originality, a definition that makes innovativeness one of the main factors of leadership. This claim is evident in many studies, some of which should be explained.

The literature implies a broad division of these studies into two groups. The first group contends that innovativeness is a very strong ingredient in transformational leadership. Transformational leadership causes the leader's innovativeness to influence the workers, encouraging them to develop new ideas and solutions (Burpitt \& Bigoness, 1997). This leadership style may be used to foster creativity at the organizational level (Hunt et al., 2004) and some agents can be used to create this creativity. Examples include incentives provided by the leader (Baer et al., 2003), the leaders' alteration of organizational rules (Amabile, 1998), the leader's facilitation of proactivity as an entrepreneur (Howell \& Higgins, 1990), and the combination of organizational culture and alterations of the organizational rules for a proper institutionalization of innovativeness (Van de Ven, 1986). It also appears that organizational culture is more critical than other agents as evidenced by its popularity from other agents. There is sound evidence that organizational culture acts as a medium for the leadership-innovativeness connection, and it is posited that this connection is affected by the intensity of the organizational culture. In this sense, scholars (e.g., Farris, 1973; Sorensen, 2002) conclude that a solid organizational culture may weaken innovativeness and that leaders should show a moderate level of control over their organizational followers to relax the organizational culture and lead to innovativeness creation. Though transformational leadership is an area of focus, a few scholars (e.g., Van de Ven, 1986; Quinn, 1988) contend that other specific leadership styles (namely participative, democratized, supportive and collaborative) may also cover innovativeness.

The second group of studies does not emphasize transformational leadership but claims that innovativeness should be a part of the leadership role in general. Studies in this group suggest using the leader's emotional intelligence to facilitate innovativeness (Zhou \& George, 2003; Suciu et al., 2010); link the leader's effectiveness with his/her encouragement of innovation through the use of his/her own innovativeness and social skills (Bossink, 2004); consider innovativeness and social skills to be two necessities for leadership capabilities (Crosby \& Bryson, 2005); and emphasize how the leader's innovativeness combined with communication skills allows him/her to engage the workers in the business goals via increased organizational commitment (Deschamps, 2003). Some studies in this group claim that the leadership-innovativeness connection is more evident if marketing is considered. These studies (e.g., Jacoby, 1972) discover that opinion leadership is essential to encourage the innovativeness of the consumers.

Despite these studies, there appears to be a shortage of empirical evidence on the leadership-innovativeness relationship (Waldman \& Bass, 1991). Some scholars believe that leadership style affects organizational innovativeness (Pierson, 1994) albeit some scholars claim that many other existing factors address innovativeness, which should empirically be explored (Waldman \& Yammarino, 1999). 


\section{Methodology}

The research, consistent with the aim of this study, aims to discover how leadership orientation and innovativeness are statistically structured and whether these structures can be merged under the concept of leadership. To achieve this aim, the authors facilitate from Luthans's (1995) leadership orientation items and also combine many items to measure innovativeness. These items include the ones prepared by Raudsepp and Hough (1977); Hurt et al. (1977); and Agarwal and Prasad (1998). As the authors cannot find any clear evidence of the exact use of these instruments in the Turkish context and as there is only one study (Ayranci, 2011) in the Turkish context that uses these instruments' items and explores their statistical structures, the authors determined to perform an explanatory factor analyses on the data gathered using the items from these instruments.

One top manager from each of the businesses in the Istanbul Leather Organized Industrial Zone participated in the research. There are 605 firms in this zone (Istanbul Leather Organized Industrial Zone, 2013), and to achieve a $5 \%$ error margin, and a $95 \%$ confidence level, size of the sample is found out to be 236 . The authors chose to obtain data from the top managers of 250 businesses to compensate for potential incomplete or invalid data. The questionnaires include the items from the mentioned instruments and were administered by a professional firm. At the end of the application, nine questionnaires were excluded and the analyses were performed on data from 241 managers.

\subsection{Limitations of the Research}

This research is limited to only one organized industrial zone in Istanbul, and therefore, generalizations regarding all the businesses in Istanbul or the entire country can not be made. This limitation is, in fact, the result of two other limitations, namely research budget and time. The use of self-reporting instruments may also be seen as another limitation as the participants may not directly and honestly provide opinions about theirselves. This limitation is also allowable according to the authors because the original instruments, which the items are taken from, are also self-reporting instruments.

Table 1. Explanatory factor and reliability analysis results for leadership orientations

\begin{tabular}{|c|c|c|c|c|}
\hline & & Style & $\begin{array}{c}\text { People } \\
\text { Orientation }\end{array}$ & $\begin{array}{c}\text { Work } \\
\text { Orientation }\end{array}$ \\
\hline \multicolumn{2}{|r|}{ Factor's Cronbach's Alpha Value } & 0.905 & 0.857 & 0.787 \\
\hline \multicolumn{2}{|r|}{ Overall Cronbach's Alpha Value } & & 0.783 & \\
\hline (1) & I make decisions about work issues. & 0.925 & & \\
\hline (2) & I want my methods to be used to solve particular problems. & 0.902 & & \\
\hline (3) & I want my subordinates to act as I request during business emergencies. & 0.883 & & \\
\hline (4) & I provide freedom up to a certain point to my subordinates. & 0.857 & & \\
\hline$(5)$ & I usually support my subordinates' business ideas & 0.736 & & \\
\hline$(6)$ & $\begin{array}{l}\text { I feel comfortable while giving some of my authority to my particular } \\
\text { subordinates. }\end{array}$ & 0.683 & & \\
\hline (7) & I have patience for haziness and latencies in our work. & 0.603 & & \\
\hline$(8)$ & I generally prefer to act after I consult particular subordinates. & 0.595 & & \\
\hline (9) & I resolve any group conflicts arising among members of the business. & & 0.932 & \\
\hline$(10)$ & $\begin{array}{l}\text { I express to my subordinates that they must be better than their rivals, as a } \\
\text { group. }\end{array}$ & & 0.828 & \\
\hline$(11)$ & I act as though I am representing all of my subordinates in the business. & & 0.801 & \\
\hline$(12)$ & I trust my subordinates. & & 0.785 & \\
\hline$(13)$ & I want my subordinates to work more. & & & 0.868 \\
\hline$(14)$ & I want my subordinates to work more enthusiastically. & & & 0.786 \\
\hline$(15)$ & I encourage my subordinates to be more productive by offering rewards. & & & 0.743 \\
\hline$(16)$ & I want my subordinates to work faster. & & & 0.687 \\
\hline$(17)$ & I encourage my subordinates to work over-time. & & & 0.642 \\
\hline
\end{tabular}




\subsection{Statistical Structures and Reliabilities of Leadership Orientation and Innovativeness}

The first step is to explore how the leadership orientation is statistically structured. To achieve this aim, the authors perform an explanatory factor analysis. The first result is that the data on leadership orientation are discovered to be suitable for factorization with a Kaiser-Meyer-Olkin (KMO) value of 0.729 and a statistically significant Bartlett's test value. There are three factors extracted, which can aggregately explain $63.46 \%$ of the overall variance. Table 1 presents the extracted factors, along with respective items and factor loadings. The table also shows the reliability analysis results.

The three extracted factors, revealed in Table 1, may be abridged as:

Style: This factor shows how the leader chooses to lead others. In this sense, style includes how the leader prefers to decide, act, provide authority to subordinates, consult subordinates, and manage work problems.

People Orientation: This factor is about the extent to which the leader focuses on the contentment of his or her subordinates and trusts them when considering the subordinates as a group.

Work Orientation: This factor uncovers how eager the leader is to get tasks done as well as the leader's desire for better productivity.

The authors continue with the explanatory factor analysis to find out the statistical pattern of the participants' innovativeness. The results indicate that the data belonging to innovativeness can be factorized (KMO: 0.694; Bartlett's test value is statistically significant). The emerging five factors can explain $64.23 \%$ of all variance overall. Table 2 includes the five factors, relevant items with factor loadings, and the outcomes of the reliability analysis.

Table 2. Explanatory factor and reliability analysis results for innovativeness

\begin{tabular}{|c|c|c|c|c|c|c|}
\hline & & Assertiveness & Flexibility & Creativity & $\begin{array}{l}\text { Rational } \\
\text { Problem- } \\
\text { Solving }\end{array}$ & $\begin{array}{c}\text { Irrational } \\
\text { Problem- } \\
\text { Solving }\end{array}$ \\
\hline \multicolumn{2}{|r|}{ Factor's Cronbach's Alpha Value } & 0.888 & 0.843 & 0.849 & 0.758 & 0.706 \\
\hline \multicolumn{2}{|r|}{ Overall Cronbach's Alpha Value } & & & 0.687 & & \\
\hline (1) & $\begin{array}{l}\text { I favor acting in a fair way than having } \\
\text { other people's acceptance. }\end{array}$ & 0.851 & & & & \\
\hline (2) & $\begin{array}{l}\text { I don't respect people who cannot keep } \\
\text { their consistencies when facing hard } \\
\text { situations. }\end{array}$ & 0.818 & & & & \\
\hline (3) & $\begin{array}{l}\text { Self-respect is much more important } \\
\text { than other people's respect. }\end{array}$ & 0.754 & & & & \\
\hline (4) & $\begin{array}{l}\text { I like people who prioritize work more } \\
\text { than fun. }\end{array}$ & 0.753 & & & & \\
\hline (5) & $\begin{array}{l}\text { I can reject benefits or amenities for the } \\
\text { sake of my goals. }\end{array}$ & 0.750 & & & & \\
\hline (6) & $\begin{array}{l}\text { I can persevere in searching for } \\
\text { solutions to very difficult problems. }\end{array}$ & 0.750 & & & & \\
\hline (7) & $\begin{array}{l}\text { I believe that success is the result of } \\
\text { hard work. }\end{array}$ & 0.693 & & & & \\
\hline (8) & I have the best ideas when I am relaxed. & & 0.801 & & & \\
\hline (9) & $\begin{array}{l}\text { I think that continuously pursuing } \\
\text { perfection is not a wise action. }\end{array}$ & & 0.781 & & & \\
\hline
\end{tabular}


(10) Sometimes asking wrong questions leads to problems to find right answers.

(11) I can sometimes quickly solve problems.

(12) Many people have problems because of taking events or other matters too seriously.

(13) I believe that I can bring about a positive change to humanity.

(14) I sometimes act in an unconventional way that surprises people in many social situations.

(15) My dreams cause my mind to arrive at many thoughts and projects.

(16) I like having new ideas rather than using other people's ideas.

(17) I believe that the most appropriate method to solve problems is to move pace by pace.

(18) I work systematically when I get and process information.

(19) I make sure that I always perform the right actions in the process of problem solving.

(20) Everything must be in order and everything must in its appropriate place.

(21) It is amendable to ask questions, which lack absolute answers.

(22) Hunches are reliable guides when solving problems.

(23) When I strive to solve a problem, I also consult my hunches, and my instincts.

(24) I can deal with a problem that I do not fully understand yet.

The five innovativeness factors seen in Table 2 can be briefly summarized as follows:

Assertiveness: This factor shows how determined the person is to reach specific goals through hard work at the expense of fun, comfort, benefits, and the approval of others if necessary.

Flexibility: This factor includes quick problem solving via flexible thinking and the acceptance of imperfection.

Creativity: This factor notes how much the person is eager to bring novelty, originality and difference.

Rational Problem-Solving: This factor includes using a systematic approach to solve problems.

Irrational Problem-Solving: This factor emphasizes the use of hunches, foresight, and the subconscious to solve problems. 


\subsection{The Merger of Leadership Orientation and the Leaders' Innovativeness within the Leadership Concept}

For the final step, the authors are curious to understand whether the leadership concept includes the combination of leadership orientation and the leader's innovativeness. This question is evaluated through the use of Structural Equation Modeling (SEM). The authors' proposed model is in Figure 1.

An evaluation of the merged model in Figure 1 indicates that the overall model is fairly realistic when the fit indices of the model are compared with the limits that are suggested in the literature (Schermelleh-Engel et al., 2003; Sivo et al., 2006; Hooper et al., 2008). Table 3 shows the relevant information.

Table 3. The merged model's fit indices

\begin{tabular}{cc}
\hline Fit Indices & Fit Indices Values \\
\hline Expected Cross-Validation Index & \\
(The index value is 7.145 for the saturated model and 38.278 for the independence & 11.173 \\
model) & 0.0968 \\
Root Mean Square Error of Approximation & 0.828 \\
Comparative Fit Index & 0.758 \\
Normed Fit Index & 0.817 \\
Non-Normed Fit Index & 0.713 \\
Parsimony Normed Fit Index & 0.829 \\
Incremental Fit Index & 0.743 \\
Relative Fit Index & 0.692 \\
Goodness of Fit Index & 0.656 \\
Adjusted Goodness of Fit Index & 0.620 \\
Parsimony Goodness of Fit Index & 0.0824 \\
\hline
\end{tabular}

Although the proposed merged model in Figure 1 appears to be realistic, there are some problematic relationships. The t-values in the merged model, in Figure 2, pinpoint that two of the leadership orientation factors, namely style $\left(\mathrm{t}_{0.05}=0.80\right)$ and work orientation $\left(\mathrm{t}_{0.05}=-1.15\right)$, are not statistically related to the leadership concept in this model. An interesting fact is that all of the innovativeness factors are successfully merged within the concept of leadership in statistical terms.

The authors are also interested in the relationships between the factors. The correlations, presented in Table 4, point out the weak relationships overall. There are, however, some key findings from Table 4. It appears that people orientation is moderately and positively related to leadership (0.313). All of the factors of innovation except assertiveness are also moderately and positively related to leadership. It is striking that flexibility (0.434), creativity $(0.510)$ and rational problem solving $(0.481)$ are more powerfully related to leadership than irrational problem solving $(0.240)$. These results suggest that innovation is considered to be beneficial for leadership and assertiveness; in other words, making many sacrifices to reach specific goals is not much favored. The participants also do not emphasize irrationality while solving problems as leaders and insist on considering their followers to be leaders.

\section{Conclusion and Recommendations}

Today's ever-changing world emphasizes competition and thus necessitates novelty, creativity, flexible thinking, and a powerful ability to solve problems; these factors can all be clustered together under the umbrella of innovativeness. In other words, innovativeness can be perceived as the key to survival and sustainable success. It is not solely innovativeness that should be glorified in this current era; the changes in many contexts also require leadership. This reality raises another necessity - the need for proper leadership. 


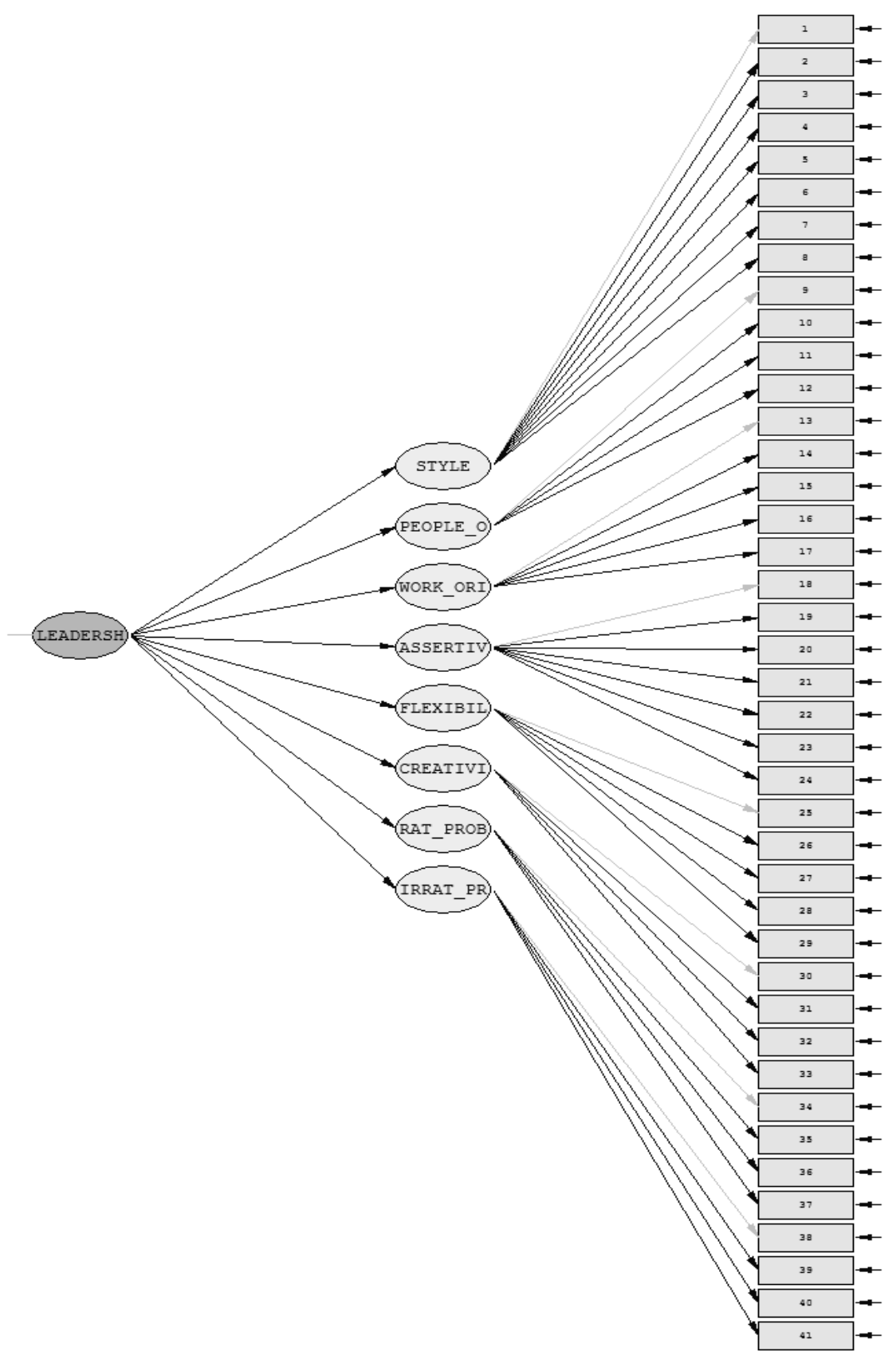

Figure 1. The merged model of leadership orientation and innovativeness

LEADERSH: Leadership; STYLE: Leadership Style (Leadership Orientation); PEOPLE_O: People Orientation (Leadership Orientation); WORK_ORI: Work Orientation (Leadership Orientation); ASSERTIV: Assertiveness (Innovativeness); FLEXIBIL: Flexibility (Innovativeness); CREATIVI: Creativity (Innovativeness); RAT_PROB: Rational Problem Solving (Innovativeness); IRRAT_PR: Irrational Problem Solving (Innovativeness). The numbers in the boxes represent the order of the items in Tables 1 and 2.

Being conscious of these facts, the authors of the current study were motivated to investigate leadership and innovativeness. These two concepts are considered together for three reasons. As mentioned earlier, leadership is thought to bring newness and originality; it is also about deciding how to manage changes and emerging situations. This management ability is related to innovativeness in the literature. However, the deficiency of the related empirical studies is a significant gap and the authors performed this study to partially fill in this gap. The authors also consider that change can best be addressed if leadership gains flexibility through the inclusion of innovativeness. Finally, the authors desire to discover which leadership orientations are related to innovativeness. 
In other words, the authors want to discover how leadership can be structured if leadership orientation and innovativeness are considered together.

With these goals in mind, the authors propose a model of leadership that includes leadership orientation and innovativeness factors. According to the preliminary results, leadership orientations are grouped into three factors - style, people orientation and work orientation. Innovativeness depends on five factors, namely assertiveness, flexibility, creativity, and rational and irrational problem solving. The model including all of these

factors is found to be fairly realistic; however, two leadership orientation factors-style and work orientation-fail to show a relationship to leadership in this model. This result indicates that leadership includes innovativeness

Table 4. Correlation matrix of the factors

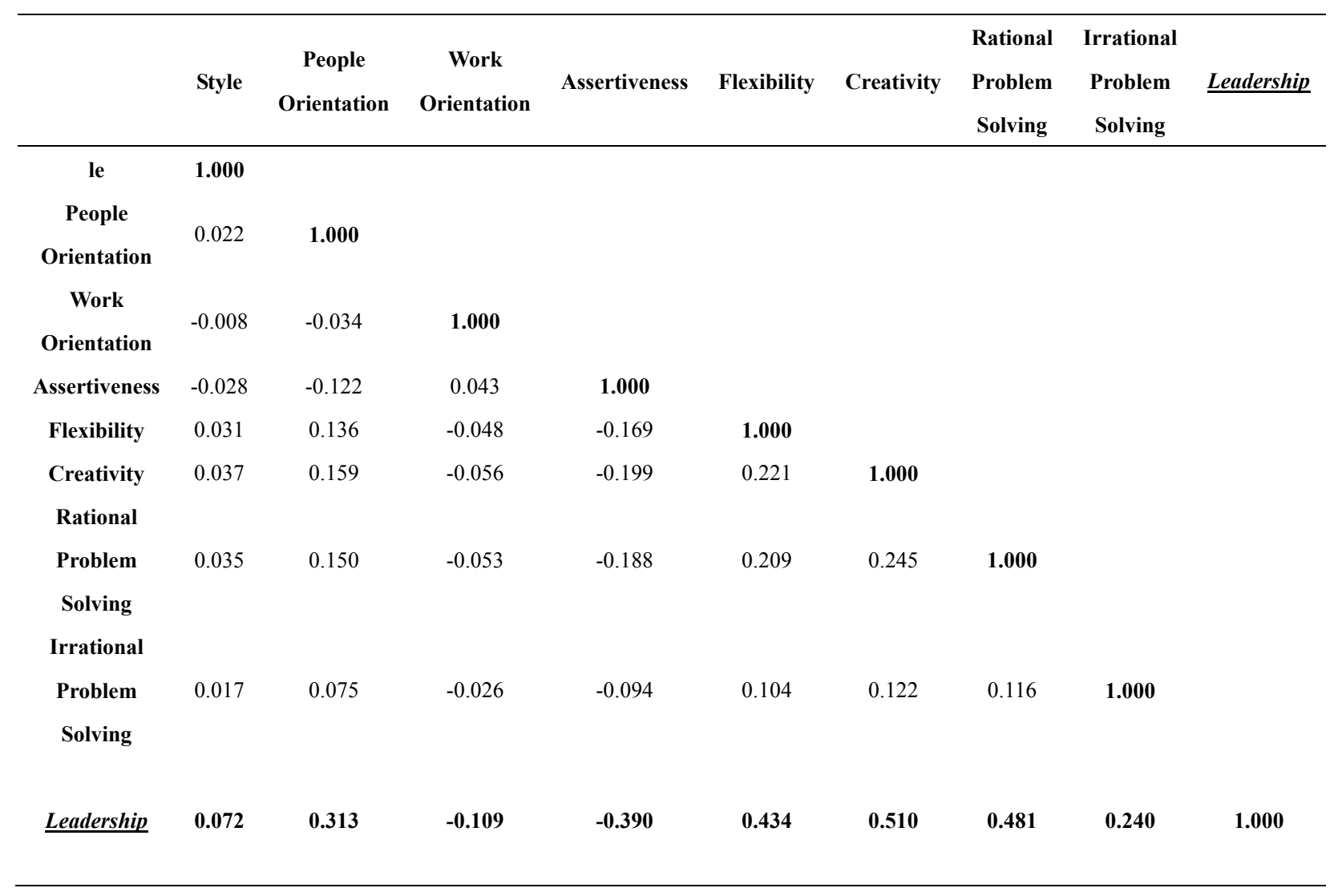

and people orientation according to the proposed model. Inferring from the relationships among the factors, innovativeness and leadership are found to be glorified together and people orientation is a considered a matter for leadership.

The authors believe that the achieved result is in conformity with the literature. Many studies claim that innovativeness is a feature of the leader, and some even posit that innovativeness is a vital source of leadership. The proposed model tested in the current study acknowledges the outcomes of the relevant studies. Another noteworthy result is that only the people orientation feature is related to leadership when innovativeness and leadership orientations are both considered within the leadership model. As the literature notes, effective leaders should not solely benefit from their innovativeness but should also use their social skills; in other words, they should appeal to their followers. The literature's focus on people and the omission of other leadership orientation factors in this research, except for people orientation, suggests that this result confirms the relevant literature as well.

Some recommendations may be made at this point. Future studies may add other leadership features aside from leadership orientation and innovativeness in their models. Interactions among these features could also be an interesting subject for exploration. As the changes in today's context require situational factors to be considered, changes or change requirements in the innovativeness and leadership orientations can also be explored within the contingency approach. Issue of culture including cultural changes, culture's effects and acculturation can also be considered in relation to leaders' innovativeness and orientation. 


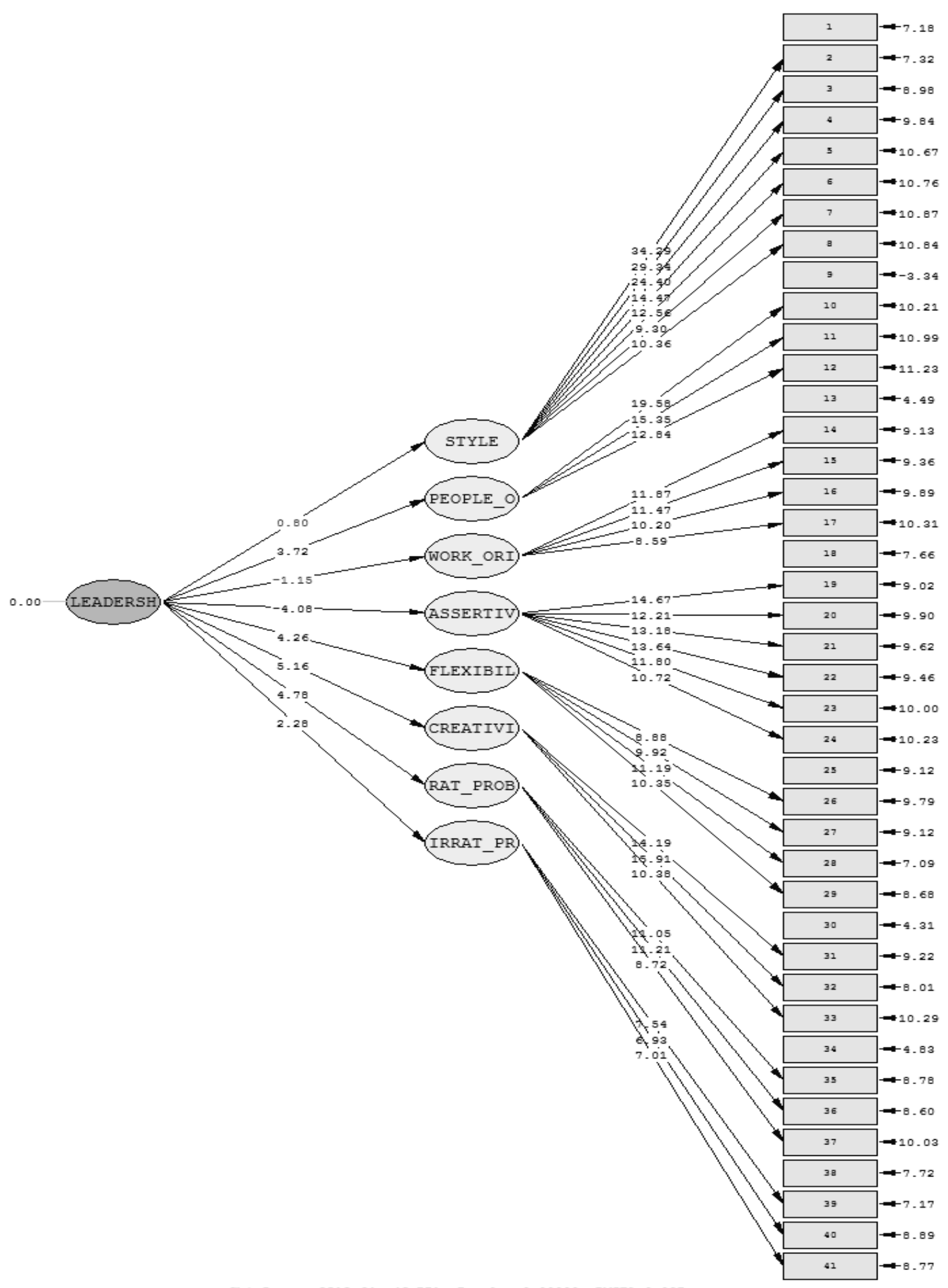

Chi-3quare=2512.64, df $=771, p-v a l u e=0.00000$, RMSEA $=0.097$

Figure 2. The $\mathrm{t}$-Values of the relationships in the merged model Note: The abbreviations are given in Figure 1. 


\section{References}

Agarwal, R., \& Prasad, J. (1998). A conceptual and operational definition of personal innovativeness in the domain of information technology. Information Systems Research, 9(2), 204-215. http://dx.doi.org/10.1287/isre.9.2.204

Ahmed, P. K. (1998). Culture and climate for innovation. European Journal of Innovation Management, 1(1), 30-43. http://dx.doi.org/10.1108/14601069810199131

Amabile, T. M. (1998). How to kill creativity. Harvard Business Review, 76(5), 76-87.

Ayranci, E. (2011). A research on the relationship between leadership orientations and the innovativeness of owner-managers in Turkish businesses. Journal of Management and Strategy, 2(1), 48-59. http://dx.doi.org/10.5430/jms.v2n1p48

Baer, M., Oldham, G. R., \& Cummings, A. (2003). Rewarding creativity: When does it really matter? Leadership Quarterly, 14(4-5), 569-586. http://dx.doi.org/10.1016/S1048-9843(03)00052-3

Bennis, W. G. (1989). On becoming a leader. New York: Addison-Wesley Publishing Company.

Bennis, W. G. (1997). Managing people is like herding cats. Provo: Executive Excellence Publishing.

Bossink, B. A. G. (2004). Effectiveness of innovation leadership styles: A manager's influence on ecological innovation in construction projects. Construction Innovation: Information, Process, Management, 4(4), 211-228. http://dx.doi.org/10.1191/1471417504ci079oa

Burpitt, W. J., \& Bigoness, W. J. (1997). Leadership and innovation among teams: The impact of empowerment. Small Group Research, 28(3), 414-423. http://dx.doi.org/10.1177/1046496497283005

Chamberlain, G. L. (2004). The evolution of business as a Christian calling. Review of Business, 25(1), 27-36.

Chesbrough, H. (2004). Managing open innovation. Research in Technology Management, 47(1), 23-26.

Chiaroni, D., Chiesa, V., \& Frattini, F. (2011). The open innovation journey: How firms dynamically implement the emerging innovation management paradigm. Technovation, 31(1), 34-43. http://dx.doi.org/10.1016/j.technovation.2009.08.007

Collins, J. (2001). Good to great: Why some companies make the leap...and others don't. New York: Harper Business.

Crosby, B. C., \& Bryson, J. M. (2005). A leadership framework for cross-sector collaboration. Public Management Review, 7(2), 177-201. http://dx.doi.org/10.1080/14719030500090519

Damanpour, F. (1992). Organizational size and innovation. Organization Studies, 13, 375-402. http://dx.doi.org/10.1177/017084069201300304

Davis, T. R. V., \& Luthans, F. (1979). Leadership reexamined: A behavioral approach. Academy of Management Review, 4(2), 237-248. http://dx.doi.org/10.2307/257777

Deschamps, J. P. (2003). Innovation and leadership. In L. V. Shavinina (Ed.), The international handbook on innovation (pp. 815-834). Oxford: Elsevier Science Ltd. http://dx.doi.org/10.1016/B978-008044198-6/50056-5

DuBrin, A. J. (1997). 10 minute guide to effective leadership. New York: Macmillan Spectrum/Alpha Books.

Eden, D. (2001). Means efficacy: External sources of general and specific subjective efficacy. In M. Erez, U. Kleinbeck, \& H. Thierry (Eds.), Work motivation in the context of a globalizing economy (pp. 65-77). Mahwah, NJ: Lawrence Erlbaum Associates.

Eigen, L. D., \& Siegel, J. P. (1989). The manager's book of quotations. New York: Amacom.

Eyal, O., \& Kark, R. (2004). How do transformational leaders transform organizations? A study of the relationship between leadership and entrepreneurship. Leadership Policy in Schools, 3(3), 211-235. http://dx.doi.org/10.1080/15700760490503715

Farris, G. F. (1973). Technical supervisor: Beyond the Peter Principle. Technology Review, 75(5), 26-33.

Galton, F. (1869). Hereditary genius. London: Macmillan. http://dx.doi.org/10.1037/13474-000

Gopalakrishnan, S., \& Damanpour, F. (1994). Patterns of generation and adoption of innovation in organizations: Contingency models of innovation attributes. Journal of Engineering Technology Management, 11, 95-116. http://dx.doi.org/10.1016/0923-4748(94)90001-9 
Guilford, J. P. (1967). Creativity: Yesterday, today and tomorrow. Journal of Creative Behavior, 1(1), 3-14. http://dx.doi.org/10.1002/j.2162-6057.1967.tb00002.x

Gumusluoglu, L., \& Ilsev, A. (2009). Transformational leadership, creativity, and organizational innovation. Journal of Business Research, 62(4), 461-473. http://dx.doi.org/10.1016/j.jbusres.2007.07.032

Herzog, P. (2008). Open and closed innovation: Different cultures for different strategies. Wiesbaden: GWV Fachverlage GmbH.

Hooper, D., Coughlan, J., \& Mullen, M. R. (2008). Structural equation modeling: Guidelines for determining model fit. Electronic Journal of Business Research Methods, 6(1), 53-60.

Howell, J. M., \& Higgins, C. A. (1990). Champions of technological innovation. Administration Science Quarterly, 3, 317-341. http://dx.doi.org/10.2307/2393393

Hunt, J. G. J., Stelluto, G. E., \& Hooijberg, R. (2004). Toward new-wave organization creativity: Beyond romance and analogy in the relationship between orchestra-conductor leadership and musician creativity. Leadership Quarterly, 15(1), 145-162. http://dx.doi.org/10.1016/j.leaqua.2003.12.009

Hurt, H. T., Joseph, K., \& Cook, C. D. (1977). Scales for the measurement of innovativeness. Human Community Research, 4(1), 58-65. http://dx.doi.org/10.1111/j.1468-2958.1977.tb00597.x

Istanbul Leather Organized Industrial Zone. (2013). Istanbul leather organized industrial zone, list of the zone's firms. Retrieved May, 2, 2013, from http://www.ideriosb.org.tr/firma-rehberi?title=\&page=12

Jacoby, J. (1972). Opinion leadership and innovativeness: Overlap and validity. In M. Venkatesan (Ed.), SV-Proceedings of the Third Annual Conference of the Association for Consumer Research (pp. 632-649). Chicago: Association for Consumer Research.

Jaskyte, K. (2004). Transformational leadership, organizational culture, and innovativeness in nonprofit organizations. Nonprofit Management and Leadership, 2(15), 153-168. http://dx.doi.org/10.1002/nml.59

Kark, R., \& Van Dijk, D. (2007). Motivation to lead motivation to follow: The role of the self-regulatory focus in leadership processes. Academy of Management Review, 32(2), 500-528. http://dx.doi.org/10.5465/AMR.2007.24351846

Luthans, F. (1995). Organizational behavior (7th ed.). New York: McGraw-Hill Inc.

Mogulkoc, K. G. (2009). The determination of creativity levels and leadership styles of executive nurses (in Turkish). Unpublished master's thesis, Halic University.

Neale, M. I. (2006). Mindfulness meditation: An integration of perspectives from Buddhism, science and clinical psychology. Unpublished dissertation, California Institute of Integral Studies.

Nolan, V. (2003). Whatever happened to Synectics? Creativity and Innovation Management, 12, 24-27. http://dx.doi.org/10.1111/1467-8691.00264

Pierson, J. L. (1994). Leadership that leads to innovation in nonprofit human service organizations. Unpublished dissertation, University of Maryland.

Quinn, R. E. (1988). Beyond Rational Management: Mastering the Paradoxes and Competing Demands of High Performance. San Francisco: Jossey-Bass.

Raudsepp, E., \& Hough, G. P. (1977). Creative growth games. New York: Jave Publications.

Riza, E. T. (2000). How to stimulate the creativity of children and adults? Education Lifetime Journal, 68, 5-12.

Rogers, E. (1983). Diffusion of innovations. New York: Free Press.

Schermelleh-Engel, K., Moosbrugger, H., \& Müller, H. (2003). Evaluating the fit of structural equation models: tests of significance and descriptive goodness-of-fit measures. Methods of Psychological Research Online, $8(2), 23-74$.

Sivo, S. A., Fan, X., Witta, E. L., \& Willse, J. T. (2006). The search for "optimal" cutoff properties: Fit index criteria in structural equation modeling. The Journal of Experimental Education, 74(3), 267-288. http://dx.doi.org/10.3200/JEXE.74.3.267-288

Sorensen, J. B. (2002). The strength of corporate culture and the reliability of firm performance. Administrative Science Quarterly, 47(1), 70-91. http://dx.doi.org/10.2307/3094891

Staub, R. E. (1996). The heart of leadership: 12 practices of courageous leaders. Provo: Executive Excellence Publications. 
Stogdill, R. M. (1948). Personal factors associated with leadership: A survey of the literature. Journal of Psychology, 25(1), 35-71. http://dx.doi.org/10.1080/00223980.1948.9917362

Suciu, S., Petcu, D., \& Gherhes, V. (2010). Emotional intelligence and leadership. Annual Economic Science Series, 16, 549-556.

Swan, J. A., \& Newell, S. (1994). Managers' beliefs about factors affecting the adoption of technological innovation: A study using cognitive maps. Journal of Managerial Psychology, 9(2), 3-11. http://dx.doi.org/10.1108/02683949410059244

Terman, L. M. (1904). A preliminary study in the psychology and pedagogy of leadership. Pedagogical Seminary, 11(4), 413-483. http://dx.doi.org/10.1080/08919402.1904.10534107

Torrance, E. P., \& Wu, T. (1981). A comparative longitudinal study of the adult creative achievements of elementary school children identified as highly intelligent and as highly creative. Creative Child and Adult Quarterly, 6, 71-76.

Ulrich, D., Zenger, J., \& Smallwood, N. (1999). Results-based leadership. Boston: Harvard Business School Press.

Van de Ven, A. H. (1986). Central problems in the management of innovation. Management Science, 32(5), 590-607. http://dx.doi.org/10.1287/mnsc.32.5.590

Vecchio, R. P. (1988). Organizational behavior (2nd ed.). Chicago: The Dryden Press.

Wakefield, J. F. (1992). Creative thinking: Problem solving skill and the arts orientation. Norwood: Ablex Publishing Corporation.

Waldman, D. A., \& Bass, B. M. (1991). Transformational leadership at different phases of the innovation process. Journal of High Technology Management Research, 2(2), 169-180. http://dx.doi.org/10.1016/1047-8310(91)90002-6

Waldman, D. A., \& Yammarino, F. J. (1999). CEO charismatic leadership: Levels-of-management and levels-of-analysis effects. Academy of Management Review, 24(2), 266-285. http://dx.doi.org/10.2307/259082

Wolfe, R. (1994). Organizational innovation: Review, critique and suggested research directions. Journal of Management Studies, 31(3), 405-431. http://dx.doi.org/10.1111/j.1467-6486.1994.tb00624.x

Zhou, J., \& George, J. M. (2003). Awakening employee creativity: The role of leader emotional intelligence. Leadership Quarterly, 14(4-5), 545-568. http://dx.doi.org/10.1016/S1048-9843(03)00051-1

\section{Copyrights}

Copyright for this article is retained by the author(s), with first publication rights granted to the journal.

This is an open-access article distributed under the terms and conditions of the Creative Commons Attribution license (http://creativecommons.org/licenses/by/3.0/). 